Journal of Education and Vocational Research

Vol. 3, No. 2, pp. 35-47, Feb 2012 (ISSN 2221-2590)

\title{
The Effectiveness of Motivational Practices in Public and Private Secondary Schools in Pakistan: A Case Study of Two Administrators
}

\author{
Asif Khan \\ Karakoram International University Gilgit, Pakistan \\ asif.khan@kiu.edu.pk
}

\begin{abstract}
This empirical study investigated the efforts of two Pakistani school administrators in dealing with the issues related to teachers' motivation. This study exclusively examined how the two administrators embedded in their practices different ways of increasing the productivity of their staff. The researcher used the following three lenses to examine the motivational behavior adopted by the school leaders: 1) degree of teachers' empowerment; 2) nature of rewards and recognition to honor teachers; and 3) pattern of communication between administrators and school staff. The study maintained that the private school administrator, unlike his public school counterpart, had a more updated knowledge in the field of education due to his exposure to professional development programs. This knowledge, which gave him a better understanding of the link between the motivational level of the teachers and the teachers' productivity, led him to initiate certain measures. Unfortunately, only a limited quantity of research explores different dimensions of school leadership in the educational context of Pakistan. Therefore, this study attempted to address related issues, such as the recruitment of school leaders and the availability of professional development opportunities.
\end{abstract}

Keywords: Pakistan, school administrators, Government school, Private school

\section{Introduction}

Research suggests that school leaders play a paramount role in dealing with the social milieu of schools, including the following: teachers' motivation, teachers' job satisfaction, teachers' sense of empowerment, rewards and recognition, and effective communication (Papanastasiou \& Zembylas, 2005; McDowelle \& Buckner, 2002; Evans, 2001; Pounder, 1993; Maehr, Midgley, \& Urdan, 1992; Grassie \& Carss, 1973). Although Western research has focused on teachers' satisfaction and dissatisfaction vis-à-vis school management (Sergiovani, 1967), developing countries have devoted little time to this research (Papanastasiou \& Zembylas, 2005; Garret, 1999). Specifically, less-developed countries, including Pakistan, have not paid much attention to the emotional dimensions of their schools (Garret, 1999). This study is conducted in the educational context of Pakistan, a country that has recently acknowledged the important role that school administrators play in the qualitative improvement of schools. This situation has two implications: First, a very small number of empirical researches about the role of Pakistani school administrators are available. Second, the motivational practices of school administrators and their impact upon the productivity of teachers have not been the exclusive focus of empirical research. In this regard, Rizvi (2008) pointed out that the educational system of Pakistan is not explicit about the "social and psychological needs of individuals within the school community". Researchers suggest that it would be helpful for school administrators to understand the "emotional nature" of their organization and their impact as a school administrator (James \& Vince, 2001). Therefore, the study investigated the efforts of two Pakistani school administrators -- one situated in a private school and the other in the government sector -- in dealing with the issues related to teachers' motivation. This study exclusively examined how the two administrators embedded different ways of increasing the productivity of their staff in their practices. While focusing on the motivational practices of two administrators, the study also examined the recruitment procedures, professional development opportunities, and definition of administrator's role in both the private and public sectors. Some of the key concepts used to examine the administrators' efforts to address the emotional aspects of their schools included: 1) delegation of responsibilities to teachers; 2) recognition of teachers' achievements through praise and rewards; and 3) patterns of communication between administrators and staff. 


\section{Literature Review}

Pakistan has a centralized educational system where the federal government is responsible for the formulation of educational policies and curriculum development, and the provincial government runs the schools through district offices. Although the government schools are the largest providers of education in Pakistan, a mushroom growth of private schools has also occurred during the last few decades. In terms of providing quality education, the private sector in Pakistan is more effective compared to the government sector (Andrabi, Das, \& Khwaja, 2008; Khan, 2005; Alderman, Orazem, \& Paterno, 2001), despite the fact that the private sector charges tuition fees that vary across localities. The private schools depend upon support from affluent individuals, non-governmental organizations, communities, and religious-political organizations. Although the private schools function out of the realm of the centralized system, they follow the national curriculum provided by the federal government. The level of administrative freedom differentiates the private schools from the government schools in Pakistan. Unlike the public school administrators, the leaders in the private schools enjoy a considerable level of freedom; this enables them to take an effective role in the development of various components of education in their schools (Memon, Ali, Simkin, \& Garret, 2000). This freedom also allows the administrators in the private sector to play an important role in the hiring and firing of their school's teaching and non-teaching staff. On the other hand, the administrators in government schools do not have a voice when it comes to the hiring and firing processes of their staff (Khan, 2004); instead, either the district level administration or the federal and provincial public service commission oversees the recruitment procedures of school staff. However, both the private and government schools both consider the duration of service more important than the level of managerial skills when offering the post of school administrator (Simkins, Sisum, Memon, 2003). Yet, the private school administrators remain more successful in fulfilling their instructional responsibilities than their public school colleagues (Memon \& Bana, 2005).

Generally, neither the private school nor the government school administrators receive professional enhancement opportunities related to school management prior to their promotion to the position of headship. Khan (2004) stated the following about the non-availability of required resources for professional development opportunities for school administrators in Pakistan: "There are some training programs, which provide in-service training to head teachers, but this happens rarely and benefits only a very limited number. This usually takes place with the support of foreign-funded projects". An individual becomes eligible for the teaching profession and leadership position in Pakistan after earning the following degrees: Primary Teaching Certificate (PTC), Certificate of Teaching (CT), Bachelors of Education (BEd), and Masters of Education (Med). As researchers note, these novice and practicing educators take a plethora of courses to earn their degrees, but these courses fail to contribute to the knowledge of the educators, particularly in terms of managerial skills (Khan, 2004; Kizilbash, 1998). Warwick and Reimers (1995) state the following characteristics of the Pakistan government school administrators: "With no clear definition of who they are and what they are supposed to do, schools heads are adrift in the educational system ... they were not trained to be leaders, did not see themselves as leaders, and did not act like leaders". Academic literature has noticed considerable differences between the instructional roles of private and government school administrators in Pakistan (Memon, Ali, Simkins, \& Garrett, 2000). The literature notes that a better understanding about various aspects of curriculum and pedagogy leads private administrators to deal effectively with matters such as teaching and learning, curriculum enrichment, staff management, and school-community relationship. Rizvi (2008) suggested that school administrators in Pakistan would benefit from training in order to acquire a better understanding of the technical aspects of their job and to develop an "understanding of how to encourage the teachers' emotional commitment towards their work".

\section{Methodology}

Since a qualitative approach, even from a small sample, helps to generate substantial amounts of information (Patton, 2002), this study adopted the case study method. Two reasons explain the rationale for this approach: 1) the topic of school management has recently been acknowledged as an important component of school improvement in Pakistan and 2) the study explores different dimensions of school leadership in Pakistan while also focusing on leadership development and recruitment procedures. Stake (1995) pointed out that the case study method is an adequate strategy for investigating contemporary issue. Likewise, Ogawa 
and Malen (1991) mentioned, "When the topic of interest has not been the subject of extensive empirical examination, an exploratory case study is a sound and sensible first step". Because of the exploratory nature of the study, no hypothesis was developed.

Sample: Study selected a private school (part of an International Non-Governmental Organization [INGO]) and a government school for this study. Both schools are in a locality where I have a long-term affiliation with the educational system. This affiliation not only provided me with the opportunity to better understand the local culture, but it also helped me to develop a working relationship with the principals and teachers of the sample schools. Furthermore, the two schools were fully equipped with many essential human and physical resources, such as teachers, science laboratories, libraries, Internet laboratories, and playgrounds. These schools also had an ideal teacher-student ratio. Therefore, my acquaintance and proximity with these schools allowed me to use the convenience sampling approach. According to Castillo (2009), when "subjects are selected because of their convenient accessibility and proximity to the researcher"; convenience sampling is an ideal approach. The all-male sample population of the study consisted of two administrators and four teachers (two from each school) representing the private and government sectors. Two criteria determined the selection of the teachers: 1) teachers must have more than three years of teaching experience and 2) teachers must have worked with the principals for the last two years. Although I sought the opinions of the principals concerning the sample population, I reserved the right to make the final selection.

Data Collection Procedures and Analysis: To collect data this study used three different tools: 1) Interview, 2) Document Review, and 3) Direct Observation. Since words have multiple meanings (Miles \& Huberman, 1984), the interview approach allows researchers to develop a deeper understanding about the topic in hand (Stainback \& Stainback, 1988). Two different interview protocols were developed, one for the principals and one for the teachers. In order to gain a better understanding of the subjects, interviews were conducted in the local language. Then recorded and transcribed the interviews, which ranged from 45 to 80 minutes, for analysis. Both the formal and informal interviews with the subjects for clarification of vocabulary and ideas were shared. According to Corbin and Strauss (2008), the process of direct observation helps researchers to generate a huge volume of data, and it puts researchers "where the action is, in a place where they can see what is going on" (p. 30). Therefore, to gain further information about the case study, I used direct observation as a data collection tool (Yin, 2009). The direct observation helped me understand the meaning of those implicit and explicit communications that occurred between the school principals and teachers in different situation on different issues. Direct observations were carried out on numerous occasions: the administrators' interactions with teachers; staff meetings; classroom visits; and the administrators' communication with non-academic staff, educational officials, parents, and communities. During the span of three months, I observed the subjects at least three to five hours each day. Journal writing and filed notes were also important components of shadowing. While conducting my observations, I made a maximum effort to not interfere with the official business of the subjects unless I needed some kind of clarification.

Study used document review as a third tool to collect data for this study. Lincoln and Guba (1981) argued that documents are stable and rich sources of information: "Documents record a variety of other evidence about the environment and people's perception about it. They are thus repositories of well-grounded data on the events or situation under investigation". Since documents can also be analyzed to notice the frequencies of events (Stake, 1995), study examined a variety of documents in order to expand my understanding about the research topic. Some of the documents that I reviewed included the following: correspondence between the school administrators and educational officials/teachers; hard copies of academic performance of students; job description of administrators; vision and mission statements of the schools; staff evaluations; minutes of meetings; and appreciation notes for teachers written by administrators. Research suggests that analysis in qualitative study is a sustained process that allows the researchers to initiate their analysis from the first day of data collection (Mertens, 2005). Therefore, I did not wait for the end of the data collection procedure; instead, I started data analysis from the first day. Since the category development is the fundamental phase of data analysis in qualitative studies (Constas, 1992), I based my analysis on certain themes and categories relevant to my research topic. I developed the relevant themes with the help of interview transcripts, documents reviews, field notes, journal writings, and previous literature. After developing the themes, I looked at the frequency of their occurrences and patterns of similarities and dissimilarities. I filtered out 
those themes that correlated with the objective of the study. Based on these themes, I made a crosscomparison of motivational practices of two principals. I then manually completed the analysis process.

Context of the Study: The venue of this study was the Gilgit-Baltistan region of Northern Pakistan. The private [sample] school, which is part of an International Non-Governmental Organization, offers education from grade eight to grade twelve to 658 middle and lower middle class students. The performance level of the private school students at the secondary level on the Board examination is high. The administrator of the private school, who earned one master's degree in chemistry and a second in Educational Leadership and Management, started his educational career as a chemistry teacher in the private school in 1999; seven years later (in 2006), he assumed the responsibility of administrator. This region has a centralized educational system that manages the public school system. The government (sample) school provides education to 415 middle and lower middle class students from grade six through grade ten. The performance level of the government school students at the secondary level (ninth and tenth grades) is not satisfactory on the Board examination. The administrator of the government school, who had more than twenty years of teaching experience, started his affiliation with this school in 2003, first as assistant and then as a full administrator. With a BSc/BEd degree, the administrator of the government school has the reputation of one of the more competent science teachers of this area.

\section{Results}

Both the administrators acknowledge the importance of the emotional aspects of their schools vis-à-vis teachers' motivation. As a result, the administrators try to become friendly and open-minded with their teaching and non-teaching staff. For example, both administrators gossip and joke with their staff; they even discuss family issues such as the arrival of new babies. Furthermore, both administrators maintain an open door policy for their staff, students, and visitors. Teachers in both schools, therefore, have a very a positive opinion about the welcoming attitude of their respective administrators. The private school teachers express a great deal of contentment when assessing the management skills of their administrator: "He is a very friendly person. When he comes to the staffroom during recess, we joke and gossip with him...the administrator always shares with us the results of the School Management Committee (SMC) meetings and the important decisions the Committee takes." I noticed that every morning the private school administrator would go to the staff room and spend some time with teachers. Likewise, the government teachers have positive opinions about some of the personal traits of their administrator. One of the teachers in the government school notes the difference between the friendly behavior of the current administrator and the less than cordial behavior of past administrators: "We had a headmaster who would not allow the teachers to come to his office. It was only after the arrival of a new headmaster that we teachers were allowed to visit the headmaster's office. Now we feel comfortable doing so." Although both administrators maintain a positive relationship with their staff, they exhibit significant differences regarding their professional responsibilities. The differing level of administrators' orientation in the private and government schools plays a major role in this behavioral disparity. The private school administrator acknowledges that his involvement in management-related interventions helps him comprehend the link between the instructional development and the social dimensions of the school. The private school administrator has a degree in Educational Leadership and Management, and he had the opportunity to learn effective interventions related to school management. This orientation leads to his philosophy that "an effective administrator should be an effective human being who understands the feelings of his colleagues". The private administrator further points out, "The administration plays a supportive role in school, so the end product is an efficient academic output which cannot be achieved if the administrative aspect is weaker."

He adds, "If the administration is weak, it will directly impact the classroom teaching." This awareness motivates him to create an environment conducive for the learning of his teachers and students. In the private school, both the administrator and teachers received clear job description and the mission statement of the school upon their appointment. In this regard, the administrator states the following: I share with the newly appointed teachers the tools of appraisal. I share with them the expectation of every indicator mentioned in the appraisal form. I hold discussions with them. If a teacher needs further explanation, I provide that teacher with clarification. Then, both the teacher and I sign the document; the document goes in the teacher's personal file. The private administrator introduced the idea of developing a job description for 
both school administrators and teachers because "without a job description, a principal cannot fully understand what his/her job responsibilities are." When he became administrator, he received a job description by the INGO with which his school is affiliated. According to the private school administrator, the provision of a job description helped him to better understand his responsibilities as a manager and as a leader. Clarity about his various responsibilities enabled him to establish the resources, both human and physical; he needed in order achieve the objectives of his institution. On the other hand, the government school administrator seems less successful in maintaining a certain standard of education, despite the fact that the teachers acknowledge his traits of respect, honesty, and kindness. Government teachers attribute the limited successes of their school to the non-availability of a proper orientation for their administrator. They mention that the administrator neither received an orientation about his responsibilities through a professional development program nor obtained a detailed job description. Therefore, according to his teachers, he has limited understanding about the importance of maintaining an academic-oriented relationship with his staff. The government teachers believe that their administrator runs the school in traditional ways that are not compatible with the needs of the modern era. One of the teacher's points out that an administrator needs more than a Bachelor's degree to efficiently run a school: "He [administrator] is a simple BSc and BEd teacher, but things have changed in schools. A simple BSc/BEd is not enough to run a school in an efficient manner. A university degree in the field of educational management is important to run today's schools."

The government administrator has little understanding of the impact that professional development opportunities would have on his performance. When I asked how the absence of proper orientation and professional development affects his job, he replied, "Like all government school administrators, I started learning through my own experience. I was not told what I had to do." One of the school teacher's points out that the administrator was not ready to assume the responsibility of headship, but was instead forced to do so: "Since he lacked an administrative disposition and skills, he did not want to be an administrator, but he assumed the responsibility as a result of directives from the higher authorities". The administrator confirms the validity of this claim by noting that teaching classes and managing schools are two different tasks: "A good teacher cannot be a good administrator, and a good administrator cannot be a good teacher". The administrator, who used to be one of the best science and mathematics teachers in the region, refers to his previous competency as evidence of his statement. It seems that the lack of proper orientation, the missing of a job description, and the unwillingness of administrator have many implications on the teaching and learning processes of the government school; the following paragraphs develop this theme. Although the government administrator allocates certain responsibilities to teachers through such committees as the one on admission and the one on discipline, teachers have reservations about the functions of these committees. Their concerns make them less motivated to take an active part in the affairs of the committees. The teachers give two reasons for their criticisms about these committees. First, their administrator does not play an instrumental role in the function of the committees. Teachers complain that their administrator does not take a stand when the members of a particular committee make decisions or forward some recommendations for his approval. They expect that their administrator should act like a leader in a war-like situation and serve as a shield against external pressures, especially when they make some decisions. Second, the teachers express their unhappiness because of their administrator's interference in the affairs and functions of the different committees, which then makes these committees less productive. In support of this argument, one of the teachers reported that the administrator personally admits students without consulting or getting advice from the Admission Committee. I understood the truth of this comment when I observed the administrator admitting a student without first consulting the Admission Committee. When a member of the Admission Committee learned of the administrator's action, he rushed to the administrator's office to lodge a protest on behalf of the Admission Committee. The administrator apologized and forwarded the case to the Admission Committee for re-consideration. Because of situations such as this one, the teachers in the government school perceive their involvement in the decision-making process as symbolic rather than instrumental; this leads them to treat the affairs of the committees with passivity and indifference.

The administrator of the private school affirms that he always seeks the opinions and suggestions of his staff concerning pedagogical development and such non-curricular activities as national holidays, parents' day, students' week, student council election, etc. After determining the interests and expertise of his staff, the administrator assigns different responsibilities to his staff through numerous committees and clubs, such as 
the Examination Committee, Library Committee, Event Committee, Code of Conduct Committee, Hiking Club, Science Club, Environmental Club, Urdu Literary Society, and English Literary Society. The administrator gives a free hand to the members of the committees to hold different academic and non-academic activities. As a facilitator and a supervisor, he tries to never impose his decisions on different committees; instead, he endeavors to understand the perspectives of the committee members. One of the teachers positively comments about this specific behavior of the private administrator as follows: "Our administrator does not demonstrate a possessive attitude. For example, if he assigns someone the responsibility of preparing a timetable, he will give that teacher a free hand. He does not tell him that he has to assign such a class to such a teacher." The private administrator seems more focused on finding ways to explore the potential of the school's staff and to utilize those talents in a productive way. As a result, the teachers in the private school are more motivated than their counterparts in the government school. The private and government administrators demonstrate discernible differences in how they recognize the achievements of their staff; the measures they take to give praise and recognition has an impact on the motivational level of the teachers in the two institutions. The administrator in the private school consistently addresses the motivational aspects of his staff through tangible rewards and written and verbal appreciation. He makes both the normative aspects that emphasize symbolism, such as public recognition, and the utilitarian aspects that emphasize the tangible awards (Pounder, 1993) an integral part of the private school culture. However, the administrator acknowledges that providing motivation to his staff is one of the most challenging aspects of his administrative responsibilities. He asserts that intrinsic motivation tended to guide teachers in the past, but the current market realties alter that behavior, causing the teachers to have more concerns about the extrinsic elements of their jobs. The administrator adds, "Teachers prefer to join government departments and schools where they have less work and fewer concerns about accountability." These circumstances strengthen the administrator's belief that tangible rewards and recognition are vital tools for motivating his staff. The teachers agree that their administrator has strong motivational skills.

In order to enhance the morale of his staff, the private administrator does not limit his efforts to a one-time event, but instead enacts reinforcements throughout the year. For instance, on the eve of World Teacher Day, he gave three books to three members of his staff through a lucky draw. On the annual Parents Day, the administrator asked the students to identify "A Best Teacher of the Year" through a secret ballot. The winning teacher not only received tangible awards, but also enjoyed the honor of public recognition for his contributions to the school. The administrator provides awards to those teachers who contribute to the overall academic performance of students, particularly on the Board examinations. Providing verbal and written appreciation of the achievements of staff is another motivational strategy of the administrator. The following note illustrates how the administrator communicates with his staff: Your role as a teacher at our school is very crucial. Your participation in school-wide activities is also commendable. By taking on extra responsibilities in addition to teaching, you have significantly added to the strength of our school...If all teachers would follow your commitment to our school and its students, our school would reach unimaginable heights of excellence in the future. I wish you the best of luck in your career and future aspirations. May God bless you? Therefore, rewards and recognition play an important role in shaping the practices of the private school and in making the school an effective one. The sensitivity of the administrator towards the achievement of his staff helps the teachers to perform better. Additionally, it leads the staff to demonstrate a great level of confidence and trust in the leadership qualities of their administrator. Unlike the private school administrator, the government administrator has minimal awareness of the importance of praise, appreciation, rewards, and recognition in his school. Because the government administrator endorses a philosophy that God is the only source who can reward his teachers for their achievement, he does not make rewards and recognition an official part of the government school culture. Therefore, teachers are not willing to look beyond certain parameters because they know that the administrator will not recognize their efforts. Although the administrator acknowledges the importance of rewards and recognition, he expresses his inability to extend some kind of benefit to the staff with the justification that he has no authority to do so. A review of the school's financial documents showed that the government allocates a certain amount of its annual budget to the government school; the administrator has the authority to spend this money according to the needs of his school. Although the administrator spares some funds for the encouragement of his staff, the government school administrator shows very little interest in addressing this aspect of his job. 
The teachers of the government school, who are critical of the role of their administrator, have concerns about the administrator's ability to motivate them. The teachers point out that by not acknowledging their achievements, the administrator reduces the chances of gaining the productive support of his teachers. One of the teachers mentions, "We don't get any written or verbal appreciation from our headmaster; we might as well get this reward from our God". Both the administrator and the teaching staff have the assumption that in government schools, the best teachers do not receive acknowledgment and the poor-performing teachers do not face punishment. In addition to the ways in which they reward and recognize their staff, the two administrators differ in how they communicate with their teachers. Research confirms the importance of positive communication by showing that the nature of the relationship between the school administrators and their staff is contingent upon the level of communication (Griffith, 2004). The administrator of the private school makes a maximum effort to maintain an effective communication channel with his staff. The administrator admits that when he assumed the responsibilities of headship, he was not an effective communicator, but he quickly realized the importance of creating a sustained relationship with his staff. This realization motivates him to become involved in the classroom processes and leads him to become engaged with his teachers beyond their official responsibilities. In order to nurture a meaningful relationship with his staff based on care and empathy, the administrator arranges a variety of in-school and out-of- school activities. For example, on the eve of a teacher's birthdays, he sends good wishes to that staff member through Short Message Service (SMS); he visits the homes of his staff during religious celebrations and festivities; and during the month of fasting, he arranges a dinner party for his staff. Through these and similar events, the administrator of the private school develops a positive communication system with his teachers. The administrator believes that whatever goodwill measures he takes will eventually contribute to the academic development of his school. The private administrator also establishes sustained contacts with the students by asking the students to express their opinions about their teachers' methodologies through written responses. These documents provide the administrator with feedback about his teachers and how they teach the curriculum from the students' perspective. On one occasion, upon the request of tenth graders, the administrator spent at least one hour discussing with these students issues they had regarding the learning environment of their classroom. The written reports, therefore, enable the administrator to become more aware of his students and their academic needs.

In addition to written communication, the administrator of the private school also embraces verbal communication. Through monthly and need-based meetings, he encourages his teachers to discuss a variety of issues ranging from the purchase of instruction-related materials to the academic progress of students. Before each staff meeting, the administrator provides the teachers with a written agenda. He later gives them the minutes of the minutes to ensure the implementation of important decisions made during the meeting. Unlike the private administrator, the government administrator does not implement communication strategies that create a positive image of his personality among his staff. While the administrator perceives his communication style as appropriate and professional, his teachers state that his style lacks professional wisdom. During a staff meeting, teachers complained to their administrator for not communicating the decisions of a previous meeting concerning their involvement in the lesson planning of their respective subjects. As a result, teachers do not integrate lesson planning into their teaching practices. In addition to academic issues, teachers raise personal issues that question the effectiveness of their administrator's communication style. The teachers report a dislike for the administrator's habit of giving nicknames to staff members. Pakistani culture does condone the use of nicknames, but it does not accept this practice in an official environment (Khan, 2010). One teacher said, "We asked [Administrator] through his close friend to stop this practice of giving nicknames because this habit is not compatible with his position, but he did not understand. I think he has developed this habit." When the administrator did not stop using nicknames, the staff mimicked him by calling him a nickname. When questioned about how he feels about this retaliatory nickname, the administrator smiled and said, "I don't care because there is freedom of expression." The teachers point out that although their administrator is a person with more than twenty years of teaching and four years of management experience, he sometimes communicates in a very irritating and dubious manner. According to one teacher, the administrator tends to use words and sentences with double meanings. When I asked the teacher to provide some examples of this unclear communication style, he responded, "Instead of saying 'you need to put this letter in the envelope,' the administrator would say to 'put it into the coffin."' The administrator validated this staff complaint by demonstrating this kind of language during the data collection period. 
Not only does the administrator of the government school have a questionable communication style, but he also has a communication gap with his staff regarding the school's academic progress due to his noninvolvement in the instructional process. Rather than visiting classes and monitoring the teaching processes, the administrator chooses to confine himself to his office to handle administrative issues. The teachers believe that this behavior does not contribute to the academic development of the school. One teacher voices the concerns of his colleagues: "For the last two years, he has not come to my class even on a single occasion...He needs to know what is going on in classes and whether or not the teachers have covered the syllabus of their respective subjects." The limited involvement of the government administrator in the classroom process leads to a higher rate of teacher absences. On one occasion, a non-teaching staff informed the administrator about the absence of three teachers, but the administrator did not take any notice of the situation. Yet, the government administrator seems to place more blame on the public educational system of Pakistan than on himself for the situation in his school. He points out that the lack of accountability mechanisms in government schools makes the teachers less vigilant about their responsibilities. As earlier mentioned, the private school administrator roots his communication strategies in the belief that he has the primary responsibility for providing an ideal learning environment to his teachers and students. Because of this philosophy, the administrator frequently engages in different educational processes, such as substitute teaching, visiting classrooms, seeking the opinions of students, providing written and verbal feedback to the teachers, and assessing the professional needs of teachers.

One teacher expresses his satisfaction about the administrator's involvement in the instructional aspect of the school as follows: "Whenever our administrator conducted an evaluation session, he identified both my weaknesses and my strengths...this gave me courage...his style of providing feedback is not sarcastic or satirical ... if I make a mistake, he politely tells me how to avoid this mistake in the future." The administrator not only keeps informed about different academic processes, but he also conveys to his staff that they are not alone in their educational endeavors. The facilitative role of the private school administrator encourages the teachers to come up with new ideas and to discuss the different ways they can contribute to the effectiveness of their school. One of the teachers comments, "When I transferred to this school, there was no Language Resource Center [LRC]. I convinced my administrator that it would be difficult to teach a particular language to students without an LRC. Because he valued my suggestion, our school now has a well-equipped LRC." The administrator acknowledges that he bases the nature of his relationship with his staff on principles of democracy where all individuals have the right to express their point of view without hesitation, even if those ideas contradict the beliefs of the administrator: "I always hope that teachers do not feel hesitant to communicate... they do come to my office...I am available; they can talk to me about any issue." As a result, teachers feel very comfortable expressing their dissenting voices during faculty meetings, feedback sessions, and other occasions. They appreciate their administrator's willingness to offer them an environment where sharing ideas is the acceptable norm.

Discussion: The internal organization of the two types of schools presents numerous commonalities, but differs in the motivational practices of the administrators; this difference influences the behavior of teachers. As a result, the academic climate of both schools varies on many levels. Although the two administrators acknowledge strong link between the academic environment and the teachers' motivation, they have different educational philosophies that stem from their affiliation with two different educational systems. Research suggests that several organizational and structural factors influence the daily business of school administrators (Hallinger \& Murphy, 1985). In this study, the private school and government school have different organizational and structural characteristics. This diversity not only leads the administrators to embrace different philosophies of teaching and learning, but it also results in their developing different interpretations of teachers' motivation. The private school administrator uses cordial relationships with his teachers to improve the school's instructional standards. The government administrator, however, does not endeavor to use the friendly relationship as a way to enrich the learning environment of his school. Both the government administrator and teachers maintain uniformity in their practices. Because they seem intent upon maintaining the status quo, their behaviors do not demonstrate a quest for change. In addition, the government administrator was less motivated to assume the charge of headship due to his perception that he could either be a good teacher or a good administrator but not both. The administrator's lack of motivation seems one of the causes of his limited involvement in the instruction-related tasks of his school. One of the 
implications of this behavior of the administrator is that the government teachers show little passion for enhancing the students' learning; the low performance of students at the secondary level illustrates this. Research suggests that teachers demonstrate a greater level of efficiency in an environment where the level of relationship is supportive (Papanastasiou \& Zambylas, 2005; Lee, Dedrick, \& Smith, 1991). The nonsupportive and non-instructional behavior of their administrator leads the government teachers to become less proactive regarding their responsibilities.

The detachment of government administrator from instructional tasks could be attributed to his nonreadiness for becoming an administrator. This lack of preparedness of the administrator points to a structural issue - the recruitment procedures in Pakistan, which also shape the practices of the sample administrator. Generally, in the public school systems of Pakistan, such factors as the length of teaching experience have more of an effect on the appointment process than the candidate's personal attributes or willingness to serve. The appointment of the government administrator reflects a practice in which the length of teaching experience emerges as the major criterion for the position. The administrator was not asked whether he felt ready for the job of headship. Moreover, teachers who suffer from exhaustion after protracted services are often asked to assume the post of headship. It is naïve to expect too much from an individual who has already lost his energies. Greenfield (1987), who observed that a person's motivation affects the way that person performs a task, asserted that a link exists between the personal interest of the administrator and the efficiency of the school: "...the absence or presence of certain personal qualities may influence the ability of the individual to be effective in specific work environment". Peterson (1987) expressed similar views that a connection exists between the motivational level of administrators and the quality of education. He added that a low level of motivation could lead administrators, despite their competency and skills, to engage in unrelated tasks. This study noticed a similar trend: the administrator was appointed against his will, and he was unable to refuse the directives of his officials. As a result, the government school administrator demonstrated a questionable leadership style and a detachment from his academic responsibilities. A comparison of the length of teaching experience between the private and public administrators suggests that, despite his limited teaching and managerial experiences, the private administrator is more proactive in carrying out his instructional and social responsibilities. Unlike the appointment of the government administrator, the appointment of the private school administrator resulted from a rigorous procedure in which he competed with other candidates. He came better prepared for the responsibilities of headship than the government school administrator, as evidenced by his involvement in a variety of instructional and motivational tasks that directly contribute to the instructional development of both the teachers and students. The appreciation notes, verbal encouragement, and the best teacher award not only reflect the motivational level of the private school administrator, but they also show his willingness to take his responsibilities more seriously.

Through the driving forces of empowerment, continuous support, and consensus-based decision-making, the private school administrator encourages his teachers to play an active role in the affairs of the school. The highly motivated teachers of the private school give their best efforts to push their students to produce maximum results (Garrett, 1999). Using a variety of methods, the private school administrator succeeds in developing a sense of security and a sense of belonging within the school community, thereby paving the way for an ideal learning. First, he motivates all the staff members to contribute to the learning of their students through collaboration; the staff members then equate the success of their students with their personal success and the success of the school. Second, the administrator encourages teachers to consistently attend school; my not observing even a single occasion where teachers were absent from their classes points to the level of their dedication to their jobs. Third, the administrator knows that the hard work of the teachers leads the students to perform significantly higher on the Board examination at the secondary and higher secondary levels. Another factor that leads the two administrators to act differently is the provision of a well-defined job description in the case of the private school administrator and the absence of such a description in the case of the government school administrator. Upon his appointment, the private school administrator received a detailed job description by the INGO. Therefore, the private school administrator had an awareness of his managerial, instructional, and social responsibilities from the very beginning of his career. He knew what kinds of resources and strategies he needed in order to achieve the instructional goals of his school. The clarity of the job and the identification of required resources enable the private school administrator to prioritize his tasks and make the administrator accountable for his job. This sense of accountability leads the 
private school administrator to take every possible measure that could enhance the productivity of his staff. Unlike the private administrator, the government school administrator was not clear about his responsibilities from the beginning of his managerial position because he did not receive any job description. Instead, he adopted a trial and error approach that did not enhance the productivity of his staff. Khan (2004) pointed out, "The absence of job manuals and the lack of defined roles make it very difficult to clearly assess the role of head teachers in Pakistan". Therefore, the government school administrator did not implement a multidimensional approach towards the instructional development of his school; instead, he confined himself to certain jobs that have limited or zero impact upon the learning climate of his school.

One of the ironies of the public educational system of Pakistan is that the government usually does not provide either administrators or teachers with a job description at the time of their appointment. Thus, government school educators rely upon the trial and error approach or certain assumptions to do their jobs. Rather than focusing on the instructional development of their schools, the government school administrators solely engages themselves in administrative related jobs, such as working on staff salaries, offering admissions, managing national events, and tackling disciplinary issues of students and teachers. A vague understanding about the responsibilities not only detaches the government school administrator from teaching and learning, but it also creates a sense of isolation and a lack of motivation within the teachers. The distancing of the government school administrator from teaching and learning leads him to become less informed about the presence and absence of school staff. Research suggests that the nature of the relationship between the administrator and teachers has a profound impact upon the overall performance of teachers and students. While elaborating on the vague role of Pakistani administrators, Warwick and Reimers (1995) asserted that the school leaders in Pakistan do not know who they are; they neither consider themselves as leaders, nor do they act as leaders. They assume teaching and learning are the responsibilities of teachers. Such a mentality, which is detrimental for the evolution of a learning friendly environment, is reflected in the practices of the government school administrator. Without a job description, there is no yardstick to evaluate his performance or to make him accountable for the poor performance of his staff. In the context of the preparation of school administrators in developing countries, Bush (2008) suggested, "Developing a clear job description, and linking candidates' experience to these requirements, provides a useful starting point". Therefore, it is essential to properly inform the school administrators about their responsibilities by elaborating their managerial and instructional responsibilities.

In addition to a job description, the availability of leadership development programs also differentiates the administrator of the private school from the administrator of the government school. The findings of this study suggest that professional development opportunities have had a profound impact upon the social behavior of the private school administrator. Additionally, a Master's degree in Leadership and Management leads the private administrator to understand the importance of concepts, such as supervision, in-school professional development programs, parental involvement, motivational techniques, and community involvement. These interventions help him to introduce unique ways of enhancing the morale of private teachers. He extends maximum support to the teachers and makes a positive impact on the quality of education. The positive attitudes exhibited by the administrator pave the way for creating a sense of recognition and satisfaction among the teachers. Therefore, teachers enjoy a considerable degree of professional satisfaction (Papanastasiou \& Zembylas, 2005). Research suggests that school managers with a positive attitude and a willingness to cooperate have a determining impact upon the educational development of their school; their behavior motivates even reluctant teachers and staff to invest their best energies for the progress of the school (Dalin, Rolff, \& Kleekamp, 1993). The private school administrator is affiliated with an INGO that offers its head teachers and teachers professional development programs at a local professional development center and higher educational institution. The INGO is famous for following systematic approaches of leadership preparation programs. However, such opportunities are not available for the mainstream private and public school administrators in Pakistan. Generally, it is assumed that the length of teaching experience is enough to offer someone the position of headship. Limited or zero understanding about the concepts related to instructional development leads the administrators to become more involved in trivial issues. As compared to the private school administrator, the government school administrator seemed less prepared for the job of headship. Because of his lack of exposure to professional development, he has limited managerial, instructional, and social competencies. Therefore, he is less successful in enhancing the productivity of his staff. Instead of introducing rewards and recognition, the administrator has a traditional 
belief that any honors will come from God. Bush (2008) asserts that the appointment of administrators without proper orientation and training is just like gambling "and it is inappropriate to gamble when the losers would be children or students".

Children in the government school are victims because the administrator cannot persuade his staff to work passionately in order to maintain a certain standard of education. For instance, he believes in democratic practices, leading him to shift some of his powers to his staff to ensure their involvement in decision-making. Unfortunately, these practices do not seem to contribute in a positive way to the overall educational climate of his school due to certain factors, such as administrator's absence from the classroom processes. Although the administrator sets higher expectations for the staff, the staff expresses serious reservations about the role of the administrator as an instructional leader. The inconsistency between the words and actions of the administrator makes the teachers less vigilant about their responsibilities. Therefore, the inconsistency between the high expectations and instructional role of the administrator has a negative impact upon the motivational level of the teachers. Since the government administrator has minimal involvement in the classroom processes, he also has little understanding of what goes on within the classrooms; he does not know if teachers completed their syllabus, if students learned, or if the teachers have the competency to teach in an adequate way. As a result, the government school has an issue of trust: the administrator is not satisfied with the performance of his teachers, and the teachers are not happy with the ineffectiveness of their administrator. However, due to his limited emotional awareness, the government administrator has a different interpretation of these challenges. Rather than blaming the issues to a lack of trust, he instead criticizes the educational system that makes the teachers less accountable. While numerous structural factors contribute to the in-effectiveness of government teachers, the role of the administrator is still crucial in neutralizing the impact of those factors. Evidence suggests that under similar circumstances, administrators with better preparation and orientation were capable of enacting positive changes in their schools. Multiple studies show that different learning opportunities enable government administrators to incorporate the ethos of emotional leadership, value-centered leadership, and pedagogical leadership models into their jobs (Rizvi, 2008; Memon \& Bana, 2005). Therefore, school leaders in Pakistan need to receive professional development that enables them to focus on the human psychology in an effective way.

Researchers tend to agree that Pakistan gives little importance to school administrators and their capacity building (Khan, 2004; Memon, 2000). Furthermore, the educators' preparation programs in Pakistan are not explicit in addressing the social dimensions of the country's schools. Therefore, both the administrators and teachers do not pay much attention this aspect of their job. At the same time, the government policies do not take into consideration teachers' motivation and satisfaction. Evidence indicates that teachers, like administrators, perform their jobs in very challenging situations; yet, the people in charge rarely address these issues. Many factors, therefore, affect the educational situation in Pakistan and limit the ability of the administrators to carry out their responsibilities. Although school administrators do not have direct interactions with students, the research indicates that the nature of their relationship with the teachers greatly contributes to the process of student learning. Therefore, school administration is a multidimensional phenomenon, and school leaders need the skills to deal with these dimensions. To lead efficiently, leaders primarily need to understand human nature because "leadership is essentially focused on people and relationship" (Begley, 2008). While linking the emotional aspects of schooling with the administrator's understanding of human psychology, McDowelle and Buckner (2002) pointed to the "lack of understanding of human nature as a major reason for failures in leadership in general and school leadership in particular". They added that school leaders require a more sophisticated comprehension of the importance of emotional intelligence. Therefore, consistent efforts are required to develop within administrators the understanding that a positive administrator-teacher relationship is prerequisite for developing quality instruction and quality schools.

\section{Conclusion and Recommendations}

Due to the small-scale research of this study, broader generalization cannot be made. Additionally, this study cannot cover the numerous factors that influence the practices of school administrators. However, this empirical research draws two important conclusions related to policymaking. First, the selection, induction, and recruitment of school leaders need to be revised. In this regard, importance may be given to the 
motivational level, managerial skills, personal interest, past performance, and instructional skills of the candidates rather than the length of teaching experience. Moreover, the process of recruitment may be linked with feedback from the last employer for greater transparency. Second, the study suggests that all school administrators in Pakistan could benefit from training opportunities in order to address the technical, educational, and emotional needs of their schools. Research acknowledges that the administrator's mastery over the factors that contribute to the motivational level of the staff could play an important role in developing effective schools. It might be helpful to conduct a study of the leadership development models of the developed and developing countries for the purpose of creating an indigenous leadership development model.

\section{References}

Alderman, H., Orazem, P. F., \& Paterno, E. M. (2001). School quality, school cost, and the public/private school choices of low-income households in Pakistan. Journal of Human Resources, 36(2), 304-326.

Andrabi, T., Das, J. \& Khwaja, A. I. (2008). A dime a day: The possibilities and limits of private schooling in Pakistan. Comparative and International Education Society, 52(3), 329-355.

Begley, P. T. (2008). The nature and specialized purposes of educational leadership. In J. Lumby., G, Crow. \& P.Pashiardis (Eds.), International handbook on the preparation and development of school leaders (21-42). New York: Routledge Taylor and Francis.

Bush, T. (2008). Leadership and Management Development in Education. Los Angeles: Sage Publications.

Castillo, J. (2009). Convenience sampling applied to research. Retrieved from http://www.experimentresources.com/convenience-sampling.htm

Constas, M. A. (1992). Qualitative analysis as a public event: The documentation of category development procedures. American Educational Research Association, 29(2), 253-266.

Corbin, J. \& Strauss, A. (2008).Basics of qualitative research. Techniques and procedures for developing grounded theory. Los Angeles, CA: Sage Publications.

Dalin, P., Rolff, G. \& Kleekamp, B. (1993). Changing the school culture. New York: The Imtec Foundation.

Evans, L. (2001). Delving deeper into morale, job satisfaction, and motivation among education professional: Re-examining the leadership dimension. Educational Management Administration Leadership, 29(3), 291-306.

Garrett, R. M. (1999). Teacher job satisfaction in developing countries. ERIC documents no 459150.

Grassie, M. C. \& Carss, B. W. (1973). School structure, leadership quality and teacher satisfaction. Educational Administration Quarterly, 9(15), 15-26.

Griffith, J. (2004). Relation of administrator transformational leadership to school staff job satisfaction, staff turnover, and school performance. Journal of Educational Administration, 42(3), 333-356.

Hallinger, P. \& Murphy, J. (1985). Assessing the instructional management behavior of principals. The Elementary School Journal, 86(2), 217-247.

James, C. \& Vince, R. (2001). Developing the leadership capability of head teachers. Educational Management Administration Leadership, 29(3), 307-317.

Khan, A. (2010). A case study exploring perceived professional development needs for secondary school administrators in Pakistan. (Unpublished PhD dissertation). Administrative and Policy Studies, School of Education, University of Pittsburgh, Pennsylvania.

Khan, H. (2004). Better school management in the Islamic Republic of Pakistan: The role of head teacher. In M. Kandasamay \& L.Blaton (Eds.). School Administrators: Core actors in educational improvement, an analysis of seven Asian countries (59-113). Paris: International Institute for Educational Planning.

Khan, S. R. (2005). Basic education in rural Pakistan. A comparative institutional analysis of government private and NGO Schools. Karachi: Oxford University Press.

Kizilbash, H. H. (1998). Teaching teacher to teach. In P.Hoodbhoy (Ed.), Education and state, fifty years of Pakistan (102-135). Karachi: Oxford University Press.

Lincoln, Y. S. \& Guba, E. G. (1981). Naturalistic inquiry. Beverly Hilla, CA: Sage Publications.

Lee, V. E., Dedrick, R. F. \& Smith, J. B. (1991). The effect of the social organization of schools on teachers efficacy and satisfaction. Sociology of Education, 64, 190-208.

Maehr, M. L., Midgley, C. \& Urdan, T. (1992). School leader as motivator. Educational Administration Quarterly, 28(3) 410-429. 
McDowelle, J. O. \& Buckner, K. G. (2002). Leading with emotion. Reaching balance in educational decision making. Lanham, Maryland: The Scarecrow Press.

Memon, M. (2000). Re-conceptualizing the role of head teachers as pedagogical leaders in Pakistan: implication for policy reforms. Education, 3(12), 6-10.

Memon, M. \& Bana, Z. (2005). Pedagogical leadership in Pakistan: Two head teachers from the Northern Areas. In J. Retallick, \& I.Farah (Eds). Transforming schools in Pakistan. Towards the learning community. Karachi: Oxford University Press.

Memon, M., Ali, R. N., Simkins, T. \& Garrett, S. (2000). Understanding the head teachers' role in Pakistan: Emerging role demands constrains and choices. International Studies in Educational Administration, 28(2), 48-56.

Mertens, D. M. (2005). Research and evaluation in education and Psychology. (2nd Ed).Thousand Oaks: Sage publications.

Miles, B. M. \& Huberman, M. A. (1984). Qualitative data analysis. A source book of new methods. Newbury Park, CA: Sage publications.

Ogawa, R. T. \& Malen, B. (1991). Towards rigor in review of multivocal literatures. Applying the exploratory case study method. Review of Educational Research, 61(3), 265-286.

Peterson, K. D. (1987). Administrative control and instructional leadership. In: Greenfield, W. (Ed.), Instructional Leadership: Concepts, Issues, and Controversies. Boston, MA: Allyn and Bacon, Inc.

Patton, M. Q. (2002). Qualitative research and evaluation methods. Thousand Oak, CA: Sage Publications.

Pounder, D. G. (1993). Organizational orientation in public and private elementary schools. Journal of Educational Research, 87(2), 86-93.

Rizvi, M. (2008). The role of school administrators in enhancing teacher professionalism: Lessons from Pakistan. Educational Management Administration and Leadership, 36(1), 85-100.

Sergiovani, T. (1967). Factors, which affect satisfaction and dissatisfaction of teachers. The Journal of Educational Administration, 5(1), 66-82.

Simkins, T. Sisum, C. \& Memon, M. (2003). School leadership in Pakistan: Exploring the head teacher's role. School Effectiveness and School Improvement, 14(3), 275-291.

Stainback, S. \& Stainback, W. (1988). Understanding and conducting qualitative research. Dubuque, IA: Kendall/ Hunt Publishing Company.

Stake, E. R. (1995). The art of case study research. Thousand Oaks: Sage Publications.

Papanastasiou, E. \& Zembylas, M. (2005). Job satisfaction among school teachers in Cyprus. Journal of Educational Administration, 42(3), 357-374.

Warwick, D. P. \& Reimers, F. (1995). Hope or Despair: Learning in Pakistan's Primary Schools. CT: Praeger Publisher.

Yin, R. K. (2009). Case study research. Design and methods. Los Angeles: Sage Publications. 